\title{
Quantitative vulnerability assessment of Corda river water basin: impacts of seasonality on water quality in the State of Maranhao
}

\author{
Késia Gomes da Silva Cavalcanti', Darlan Ferreira da Silva", \\ Neuriane Silva Lima'I', Rita de Cássia Mendonça'v, \\ Wallace Ribeiro Nunes Neto ${ }^{\mathrm{V}}$, Maria Raimunda Chagas Silva VI
}

\begin{abstract}
The Corda river is the main source of fresh water for recreation, leisure, supply and irrigation to the municipality of Barra do Corda - MA. The objective of the present study was to evaluate the physicochemical parameters of Corda river's water using the methodology described by the American Public Health Association. The water samples were collected in the seasonal period spanning between February and September of the year of 2018. The parameters which were analyzed during the study were $\mathrm{pH}$, conductivity, turbidity, total dissolved solids and salinity, besides concentrations of nitrite, nitrate, and total phosphorus. Three principal components were identified during the PC Analysis. Those components explain more than $74 \%$ of the total variance observed during the rainy and dry season. Axis 1 and 2 included variables which were related to quality of water and could be affected by the change in seasons. The results indicated that $\mathrm{pH}(7.11), \mathrm{P}\left(2.82 \mathrm{mg} \mathrm{L}^{-1}\right), \mathrm{NO}_{3}^{-}\left(3.23 \mathrm{mg} \mathrm{L}^{-1}\right)$, turbidity (35.82 NTU) and conductivity $(35.83 \mu \mathrm{S} / \mathrm{cm}$ ) parameters were most affected by changing from rainy to dry season.
\end{abstract}

Keywords: Physicochemical parameters; Contamination; Water; Principal component analysis

\section{RESUMO}

O rio Corda é a principal fonte de água doce para recreação, lazer, abastecimento e irrigação do município de Barra do Corda - MA. O objetivo do presente estudo foi avaliar os parâmetros físicoquímicos da água do rio Corda usando a metodologia descrita pela American Public Health Association. As amostras de água foram coletadas no período sazonal entre fevereiro e setembro do ano de 2018. Os parâmetros analisados durante o estudo foram $\mathrm{pH}$, condutividade, turbidez, sólidos totais dissolvidos e salinidade, como também as concentrações de nitrito, nitrato e fósforo total. Três componentes principais foram identificados durante a análise do APC. Essas componentes explicaram mais que $74 \%$ da variação total observada durante a estação chuvosa e seca. Os eixos 1 e 2 incluiram as variáveis relacionadas à qualidade da água e que poderiam ser afetadas pela mudança de estação do ano. Os resultados indicaram que os parâmetros $\mathrm{pH}(7,11), \mathrm{P}\left(2,82 \mathrm{mg} \mathrm{L}^{-1}\right), \mathrm{NO}_{3}^{-}\left(3,23 \mathrm{mg} \mathrm{L}^{-1}\right)$, turbidez $(35,82 \mathrm{NTU})$ e condutividade $(35,83 \mu \mathrm{S} / \mathrm{cm})$ foram os mais afetados pela mudança da estação chuvosa para a seca.

Palavras-chave: Parâmetros físico-químicos; Contaminação; Água; Análise de componentes principais

\footnotetext{
' Graduada em Farmácia, Universidade CEUMA - jneto152@gmail.com

" Doutor em Química Analítica, Universidade CEUMA - darlanveggito@hotmail.com

III Graduanda em Engenharia Ambiental, Universidade CEUMA-neuriannylima@gmail.com

IV Doutora em Biologia de Fungos, Universidade CEUMA - ritamend30@gmail.com

${ }^{\vee}$ doutorando em Biodiversidade e Conservação, Universidade CEUMA- wallaceneto2010@hotmail.com

VI Pós- Doutorado, Universidade CEUMA - marirah@gmail.com
} 


\section{INTRODUCTION}

Deterioration in the quality of groundwater intensifies in the large urban centers, mainly due to the usage and occupation of the soil. In turn, this phenomenon generates diverse effluents that return to the water bodies. They reduce the water quality and affect seasonality at a lesser scale. Therefore, monitoring changes in the features of groundwater using chemical analysis is an important measure to evaluate its quality. It serves as an indicator of the possible sources of groundwater contamination which can significantly alter the chemical properties of water; thereby, compromising the overall balance of the natural system, causing economic losses and making the consumption of water unfeasible (CARVALHO et al., 2015).

According to RIBEIRO et al. (2016) and ANDRADE et al. (2016) water is an essential element of life and its use is indispensable to a wide spectrum of human activity, including irrigation, public and industrial consumption, leisure and recreational activities. Above all, water presents itself as the main constituent of all living organisms.

Demographic and industrial growth are the most common causes that affect rivers and lakes in the recent years. Water resources have been used inadequately during the aforementioned processes (RIBEIRO et al., 2016).

The Corda River has been one of the main sources of income for the population since many years. It yields revenue through fishing, besides receiving numerous tourists for various purposes throughout the year and contributing to the landscape of the municipal aquatic ecosystem with its extension and beauty of its Waters (Brazil, 2013; CODEVASF, 2014; BARRA DO CORDA, 2015).

It is noticeable that man maintains direct contact with the river water and modifies its properties throughout the year. Thus, it is necessary to analyze the concentrations of some nutrients and substances present in the water which are essential to identify its uses and health impacts on the riverside community as well as the visitors (VASCONCELOS, VIVEROS and ARRAZ, 2012).

The objective of this study was to evaluate the physicochemical characteristics (conductivity, turbidity, total dissolved solids and salinity, besides concentrations of 
nitrate, nitrite, and total phosphorus) the Corda River water and their correlations with seasonality.

\section{METHODOLOGY}

The study site comprised of the Corda River (Figure 1) which is located in the State of Maranhão. It has a watershed of $4700 \mathrm{~km}^{2}$. The source of the Corda River is located in the Serra da Canela mountain range at a height of about $450 \mathrm{~m}$ above the sea level. It is currently located inside a large farm called Agroserra (agrobusiness farm - Formosa da Serra Negra), which is close to city of Fortaleza dos Nogueiras. Its main tributaries are the Pau Grosso and Ourives rivers, besides some streams like the Pintado, Estiva, Fundo, Baixão do Sabonete, and Baixão Lagoa de Dentro.

Figure 1 - Corda River location and sampling points

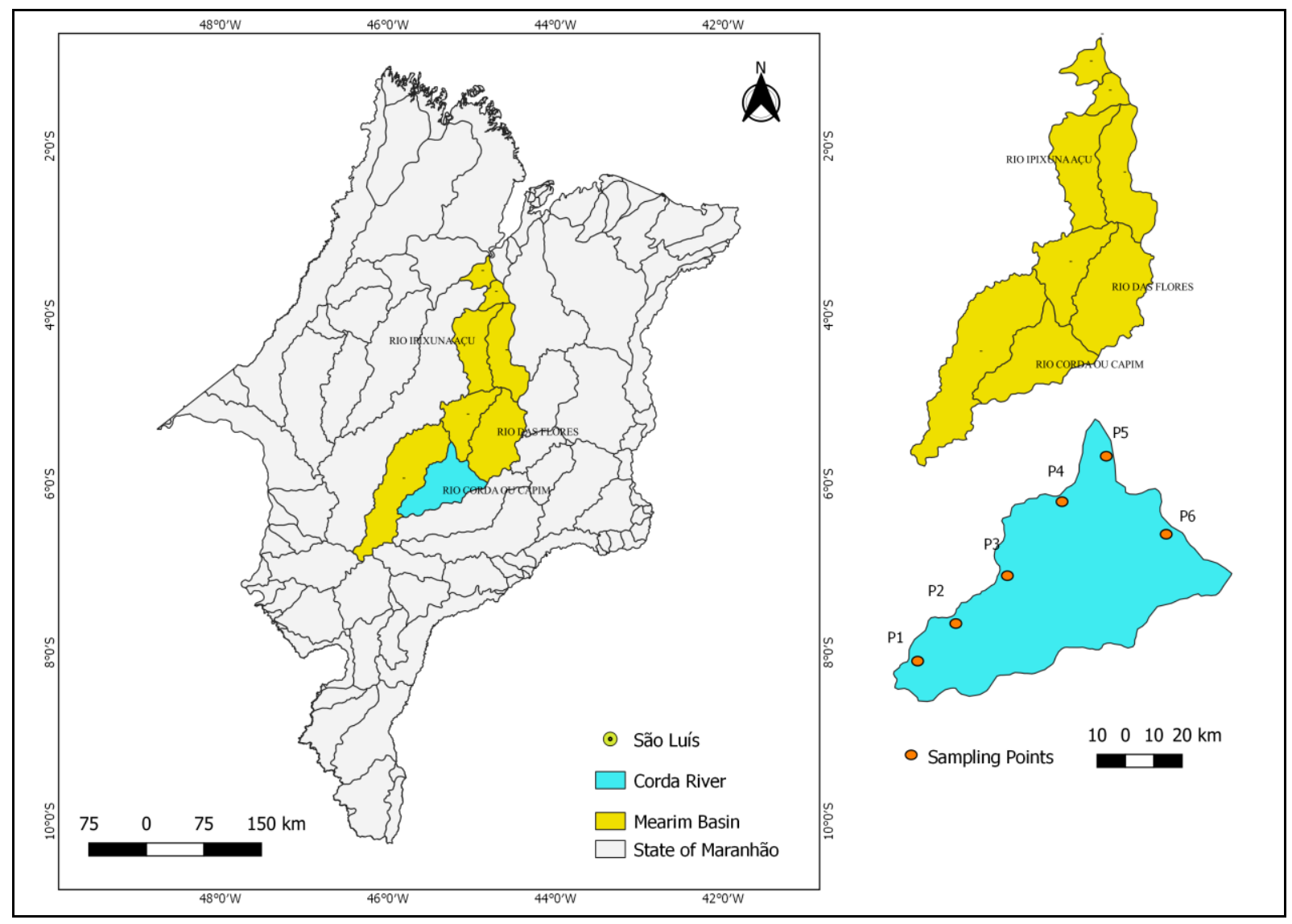

For the analysis of water, 6 spatially distributed points (P1, P2, P3, P4, P5, and P6) (Figure 1) were plotted along the Corda River. P1 was located in the Mete-Mete 
balneary, P2 was located in Tabocas balneary, P3 was located between the rivers Corda and Mearim, P4 was located downtown, P5 was situated near the sewage waste hospital and P6 was located in another balneary near to hospital.

Samples used in the physicochemical analysis were collected during two different periods that is, rainy season (between the months of February 2018 and July 2018) and dry season (in the month of September 2018), by following the methodologies specified by the American Public Health Association (APHA, 2012). The samples were collected in polyethylene bottles and aliquots of the same were divided for examining the chosen parameters, namely, $\mathrm{pH}$, total dissolved solids (TDS), turbidity, salinity, electrical conductivity, as well as concentrations of nitrate, nitrite and phosphorus. All vials were stored in the refrigerator before analysis. To evaluate the effect produced by seasonality, the data derived from the analysis was separated as per sampling periods. Thus, one set of data was prepared for the rainy period $(n=$ 3) occurring in the months of February and July, while another set of data contained the readings taken during the dry season $(n=3)$ which occurs in the month of September. Table 1 shows the maximum values for the specified parameters as stipulated by the CONAMA Resolution 357/05.

Table 1 - Maximum values allowed according to CONAMA Resolution 357/2005

\begin{tabular}{|c|c|c|c|c|c|c|c|c|}
\hline & $\mathrm{pH}$ & $\begin{array}{l}\text { Cond. } \\
(\mu \mathrm{S} / \mathrm{cm})\end{array}$ & $\begin{array}{l}\text { TDS } \\
\left(\mathrm{mg} \mathrm{L}^{-1}\right) \\
\end{array}$ & $\begin{array}{l}\text { Turb. } \\
\text { (NTU) }\end{array}$ & $\begin{array}{l}\text { Sal. } \\
(\%)\end{array}$ & $\begin{array}{l}\mathrm{NO}_{2}^{-} \\
\left(\mathrm{mg} \mathrm{L}^{-1}\right)\end{array}$ & $\begin{array}{l}\mathrm{NO}_{3}^{-} \\
\left(\mathrm{mg} \mathrm{L}^{-1}\right)\end{array}$ & $\begin{array}{l}P \\
\left(\mathrm{mg} \mathrm{L}^{-1}\right)\end{array}$ \\
\hline Values & $6.0-9.0$ & 100 & 500 & 100 & $<0.5$ & 1 & 10 & 0.1 \\
\hline
\end{tabular}

Cond. (conductivity), Turb. (turbidity), Sal. (salinity), TDS (Total Dissolved Solids), $\mathrm{NO}_{2}{ }^{-}$(nitrite), $\mathrm{NO}_{3}{ }^{-}$(nitrate), $\mathrm{P}$ (phosphorus).

Multivariate statistical methods are widely applied for classification, model and interpret a large data sets, and also, reduce the complex dataset with minimum loss of the original information. Principal Component Analysis (PCA) is a pattern recognition technique that groups the objects into classes (clusters) based on their similarities within a class and dissimilarities between different classes. The results of PCA help to interpret the data and indicate patterns (HAJIGHOLIZADEH and MELESSE, 2017). 
For the statistical evaluation of the results the one-way ANOVA was applied, using Fisher LSD means comparison test using the Origin pro 8.0 software. Multivariate analysis techniques, specifically Principal Component Analysis (PCA) conducted using Minitab 17 software (HONGYU, 2015) were also used as an additional tool.

\section{Results}

To evaluate the effect of seasonality, the results were separated on the basis of their collection period i.e. into rainy and dry seasons. Figures 2, 3, 4 and 5 shows the One-Way ANOVA of the spatiotemporal dynamic to physicochemical parameters and Figure 6 shows microbiological analyzes performed in the rainy and dry season of the Corda river water.

Figure 2 - One-Way ANOVA of the spatiotemporal dynamic of $\mathrm{pH}(\mathrm{A})$ and conductivity (B) parameters of the Corda River during the dry and rainy seasons

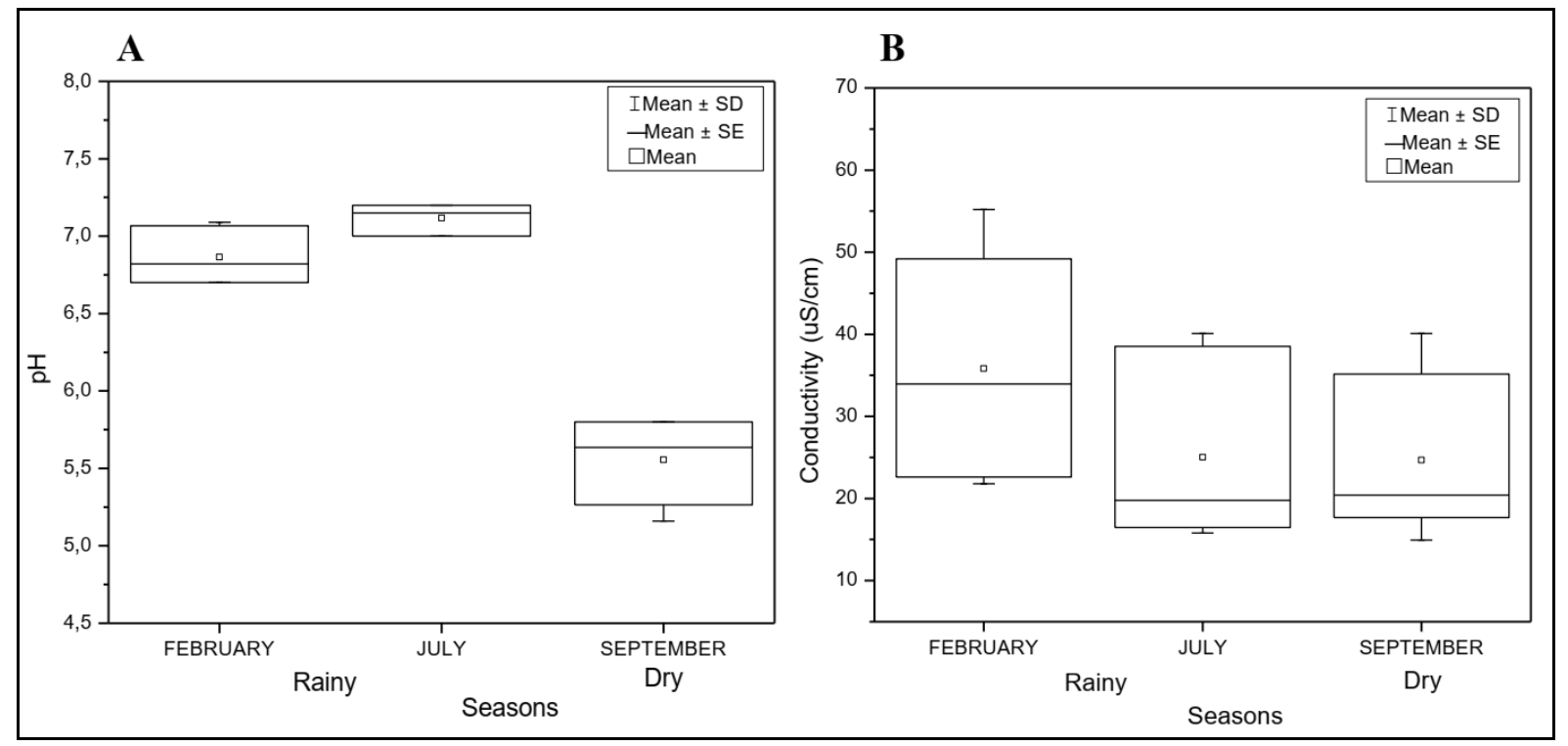

According to Fernandes (2017), pH represents the concentration of hydrogen ions $\left(\mathrm{H}^{+}\right)$. It can indicate if the water is acidic, basic, or neutral in nature. Figure 2 show that the $\mathrm{pH}$ was lower in the month of September (dry period) as compared to that obtained during the rainy months (February and July). As evident, the former is also inadequate as per the limits established by the CONAMA legislation, which allowed 
variation from 6 to 9 in the $\mathrm{pH}$. The average $\mathrm{pH}$ was low (5.55) during the dry period as compared to the averages obtained for the months of February (6.86) and July (7.11). These observations are consistent with the studies carried out by Belluta et al. (2016). According to Lordelo et al. (2017), high values of conductivity indicate that the water tastes unpleasant and may cause digestive problems. As per the collected data, no significant variation between the conductivity values obtained during the dry and rainy periods could be observed. The TDS presented distinct values throughout the rainy and dry periods. Contrary to the month of July and February, the TDS was lower during the dry period.

Figure 3 - One-Way ANOVA of the spatiotemporal dynamic of turbidity (A) and salinity (B) parameters of the Corda River during the dry and rainy seasons

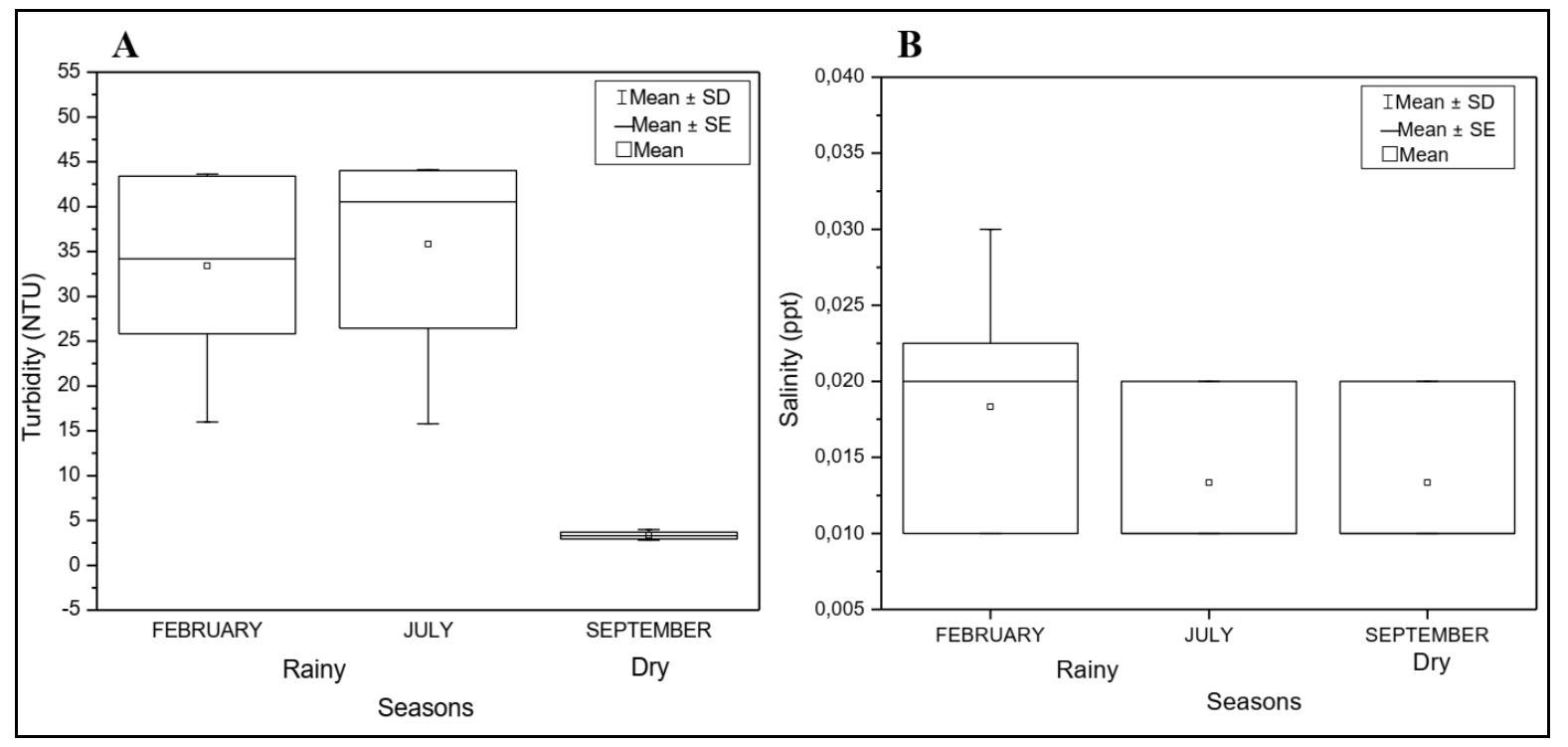

Turbidity analysis is used to assess the ability of water to disperse radiation. According to Da Conceição and Bonotto (2017), turbidity of water is caused by increased concentration of organic and inorganic matters. Upon compariso n, it could be observed that the turbidity was higher in the rainy period (33.40 a 35.82 NTU). However, the mean turbidity values were lower in the dry period (3.33 NTU) as compared to the other months. This observation points at the direct relationship between the aforesaid parameter with the rainy season. Bezerra et al. (2017) who 
studied the variation in the turbidity of the Santa Maria da Vitória River also obtained similar results.

According to Freitas (2016), waters with high salinity indices are unfeasible for human consumption. The salinity values obtained in the present study were invariably within the limits established by CONAMA $(<0.5 \%)$ during the months under observation, i.e. 0.01 ppt. Unlike the studies conducted by Coimbra et al. (2016) which demonstrated the influence of seasonality and the dilution of salt water in the Maracaípe - PE River by presenting high values of salinity of the sampling points, the present study observed that salinity levels were not affected by rainy and dry periods.

Figure 4 - One-Way ANOVA of the spatiotemporal dynamic of Total dissolved solids (A) and phosphorus (B) parameters of the Corda River during the dry and rainy seasons

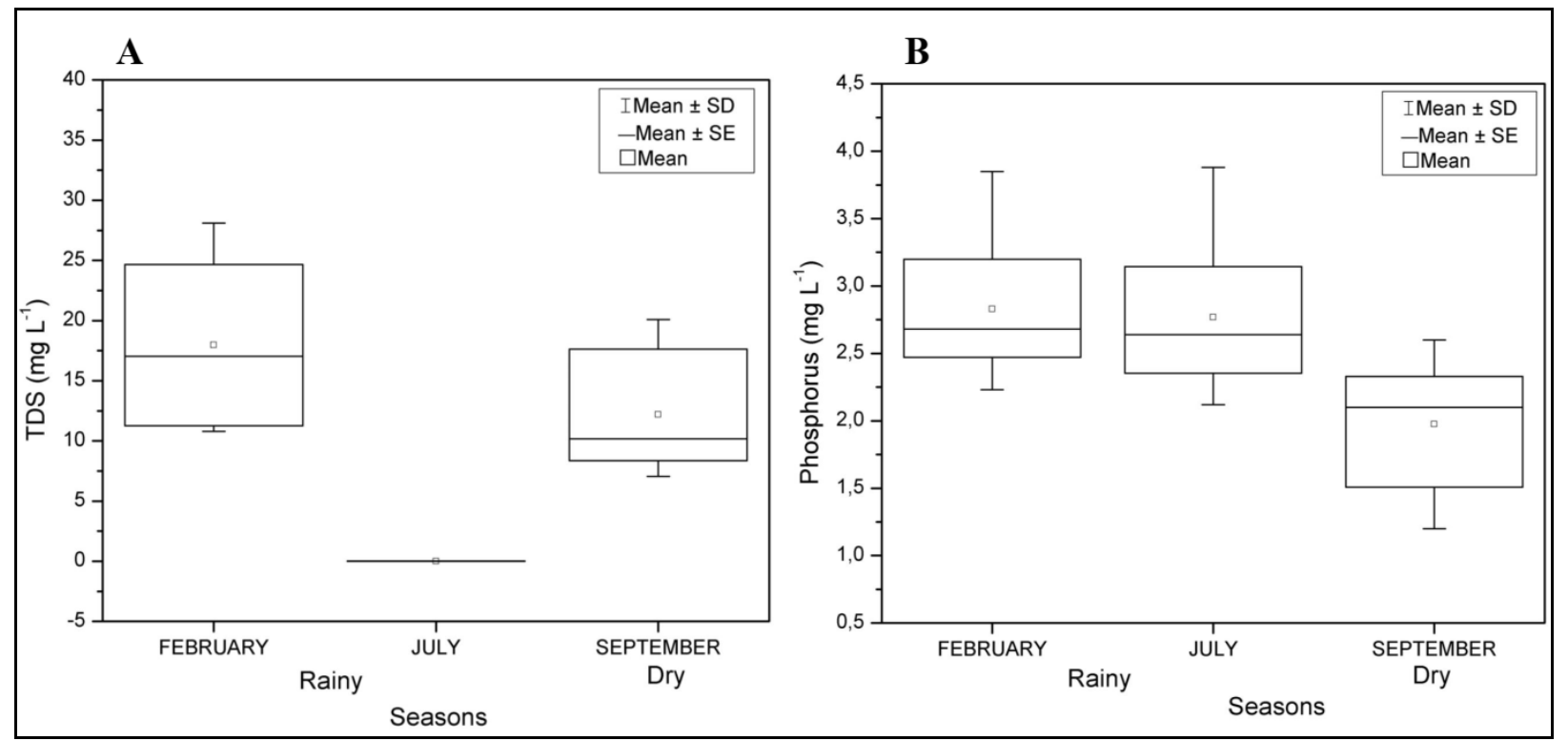

The TDS presented distinct values throughout the rainy and dry periods. Contrary to the rainy season (means of $17.98 \mathrm{mg} \mathrm{L}^{-1}$ ), the TDS was lower during the dry season, showing the value of $11.01 \mathrm{mg} \mathrm{L}^{-1}$.

According to Da Silva and Vargas (2017), phosphorus occurs in natural waters and effluents in the form of phosphates. The concentration of phosphates is widely used as a parameter to classify natural waters. When it is found in excess (above 0.1 $\left.\mathrm{mg} \mathrm{L}^{-1}\right)$, it indicates that an anthropogenic action had occurred which could have primarily been caused by domestic effluents (Munin et al., 2017). Upon comparing the 
seasons' results, it was observed that the data obtained in the dry period $(\approx 1.97 \mathrm{mg} \mathrm{L}$ 1) was different in comparison to the one derived during February and July ( $\approx 2.82$ and $2.76 \mathrm{mg} \mathrm{L}^{-1}$, respectively). This finding showed that rain could contribute to the increasing levels of contamination of the aforementioned and other attributes. This inference is consistent with the results deduced by Gois et al. (2017) who studied the quality of the Indios river water.

Figure 5 - One-Way ANOVA of the spatiotemporal dynamic of nitrite (A) and nitrate (B) parameters of the Corda River during the dry and rainy seasons

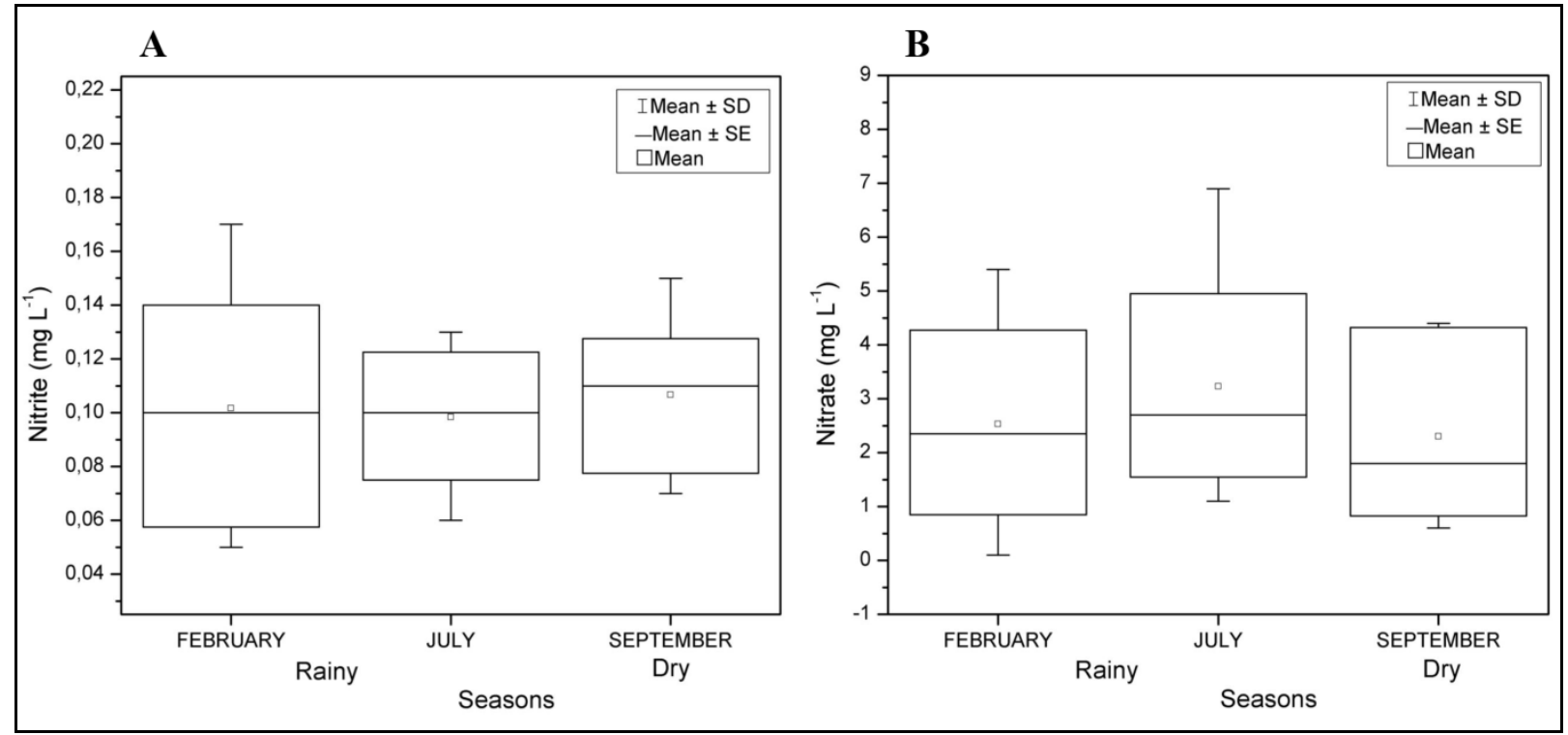

Nitrogen is present in water in different forms, such as nitrite, nitrate, and ammonia. As per the obtained data, there was no significant variation between the concentration of nitrogen in the samples extracted during the dry and rainy periods. Sassoma et al. (2015) had studied the physicochemical parameters of the Catumbela River. They also obtained similar results in their study.

Nitrate is found in small quantities in surface waters and at high levels in groundwater. It is the main form of nitrogen found in waters. The values derived during the study showed that nitrate concentration was significantly affected in the month of September (dry period) as compared to the rainy months (February and July). Nonetheless, it remained in the limits established by the CONAMA legislation that is, nitrate levels remained below $10 \mathrm{mg} \mathrm{L}^{-1}$. The average nitrate concentration was 
higher $(\approx 4.00)$ in the dry month as compared to the averages observed in the months of February and July $(\approx 2.00)$.

Figure 6 - Microbiological analyzes in water samples in the dry (september), rainy (February and July) in the municipality (Barra do Cordal / MA)

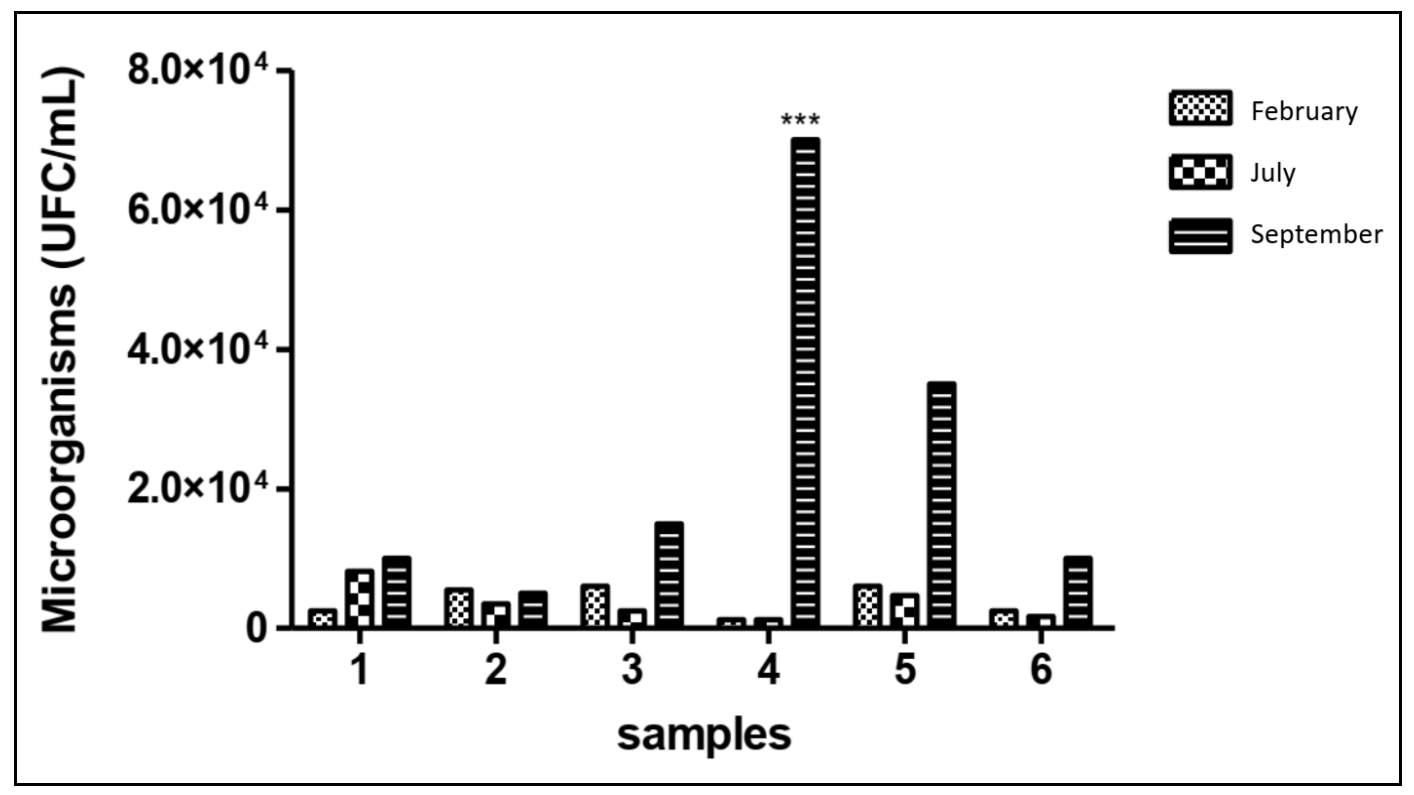

According to Ferreira et al., 2017, to evaluate the sanitary conditions of natural waters, coliform group bacteria are used, as they indicate fecal pollution since they are always present in the human and animal intestinal tract, being eliminated in feces. Regarding Escherichia coli, CONAMA Resolution 357/05 allows the concentration of up to $1,000 \mathrm{E}$. coli in $100 \mathrm{~mL}$ of water, in which all points in the three months presented values above the recommended. In February, there was a very significant variation between P3 and P4 from $60 \times 10^{2}$ UFC/100 mL to $12 \times 10^{2}$ UFC/100 mL. In July, the highest amount was in P1 with $82.5 \times 10^{2}$ UFC/100 mL and the lowest amount in P4 with $12 \times 10^{2}$ UFC/100 mL. In the dry period, the highest amount was in P4 with $70 \times 10^{3}$ UFC/100 mL, and the lowest in P1e P6 with $10 \times 10^{3} \mathrm{UFC} / 100 \mathrm{~mL}$ both. These results are similar to those of Kolm, Siqueira \& Machado (2016) where there was also an increase in the number of bacteria in the dry period, because the dry period there is no moisture which ends up benefiting the growth of bacteria of this class.

As a way to distinguish the effects produced by seasonality upon the sampled points, two Principal Components (PC1 and PC2) analysis were conducted for the 
physicochemical parameters $(\mathrm{pH}, \mathrm{TDS}$, turbidity, salinity, electrical conductivity, concentration of nitrate and nitrate and total phosphorus content) observed during the dry period as well as the rainy season (Figure 6). Two-dimensional score plots were created from the relationship between the Principal Components to visualize the two periods. In addition, loading plots were also designed for the analyzed physicochemical parameters. Through the analysis of the plots the dispersion between the sampling points could be visualized and it could highlight the distinction between the points, as well as the tendency of points P4 and P6 analyzed in February (rainy season) to the points analyzed in the September (dry season).

Figure 6 - Loading and score plot of the physicochemical parameters and analyzed sampling points, for the rainy and dry seasons. $\mathrm{P}$ (Phosphorus), $\mathrm{NO}_{3}{ }^{-}$(Nitrate), Turb. (Turbidity), Cond. (Conductivity), Sal. (Salinity), TDS (Total Dissolved Solids), $\mathrm{NO}_{2}{ }^{-}$ (Nitrite). P1, P2, P3, P4, P5 (Sampling points). -F (February), -J (July), -S (September)

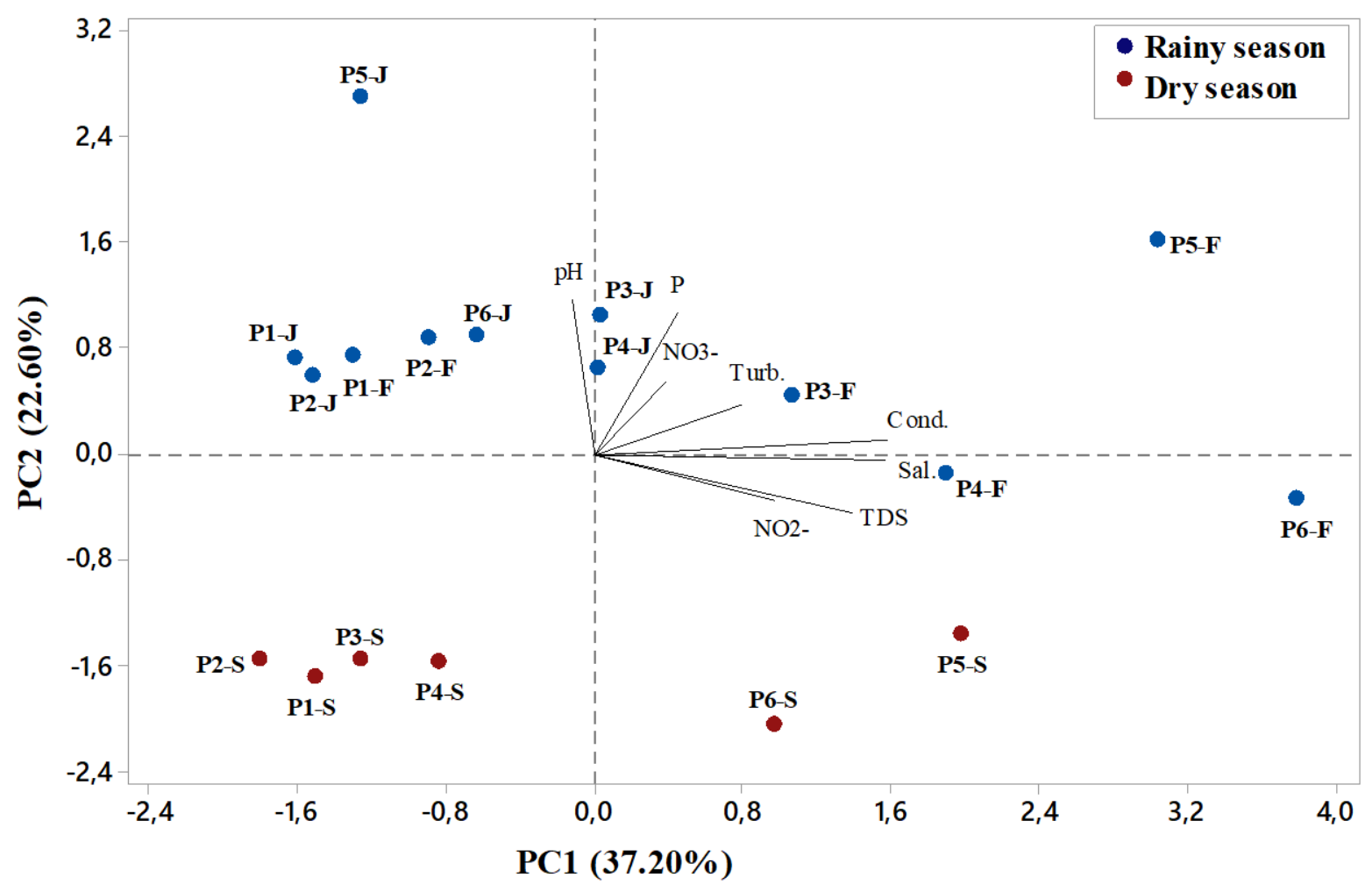


Table 3 - Principal component analysis of the physicochemical parameters of the rainy and dry seasons

\begin{tabular}{lccc}
\hline Parameters & PC1 & PC2 & PC3 \\
\hline $\mathrm{pH}$ & -0.041594 & 0.645426 & -0.284256 \\
Conductivity & 0.532992 & 0.064105 & 0.179729 \\
Turbidity & 0.266062 & 0.202737 & -0.656159 \\
Salinity & 0.528383 & -0.025940 & 0.108127 \\
$\mathrm{TDS}^{-}$ & 0.465489 & -0.245298 & -0.061053 \\
$\mathrm{NO}_{2}{ }^{-}$ & 0.327820 & -0.191040 & -0.185458 \\
$\mathrm{NO}_{3}{ }^{-}$ & 0.129759 & 0.300913 & 0.626945 \\
$\mathrm{P}$ & 0.152409 & 0.591882 & 0.116095 \\
Total variance (\%) & 37.20 & 22.60 & 15.00 \\
Cumulative variance (\%) & 37.20 & 59.8 & 74.80 \\
\hline
\end{tabular}

*Significant factors (>|0.5|). TDS (Total Dissolved Solids), $\mathrm{NO}_{2}{ }^{-}$(nitrite), $\mathrm{NO}_{3}{ }^{-}$(nitrate), and $\mathrm{P}$ (phosphorus).

The main objective of PCA is to reduce the data volume. The reduction in the data volume is enabled through converting the data into a large number of variables with internal correlations so that most of the information existing in the data would be retained. The reduction of the data volume as well as the conversion into a new space is known as the principle component. The prioritization of the principle components is based on the coverage of most of the explained variance within the variables (Behbahani et al., 2017). From Table 3 it can be seen that three principal components (PC 1-3) were significant in the model description, explaining, statistically, $74.80 \%$ of the variance among data, i.e., cumulative variance is resulted by PC1 (37.20 \%) plus PC2 (22.60 \%) (represented graphically), and PC3 (15.00\%), thus, representing $74.80 \%$ of variance. The values highlighted in bold were considered significant in the mathematical model, where, the conductivity and the salinity were the dominant variables in $\mathrm{PC1}$; the $\mathrm{pH}$ and phosphorus content in $\mathrm{PC2}$ and the turbidity and nitrate content in $\mathrm{PC}$, that is, confirming that these six variables are the most affected by seasonality.

This type of analysis allows to distinguish the effects of seasonality on the physicochemical parameters analyzed in the present study. Principal Component 1 which was generated from the analyzed parameters of the rainy season (Figure 6) could explained $74.80 \%$ of the total variation of the studied data. It could also stand 
evidence for the correlation $(>|0.50|)$ between conductivity and salinity parameters in $\mathrm{PC} 1 ; \mathrm{pH}$, and phosphors content in PC2 and, turbidity and nitrate in PC3, thereby, indicating that the aforesaid parameters were sensitive to seasonality (Table 3). This observation could be verified through the loading plot where these parameters are farthest from the axis of PC1 (Figure 6). The highest correlation coefficients were found to be related to conductivity, salinity and nitrite concentration. Therefore, from the interpretation of the correlation coefficients, it could be inferred that the parameters which have negative correlation coefficients $(\mathrm{pH}$, nitrite, and nitrate concentration) decrease with change of season.

\section{CONCLUSION}

In general, the calculated values of the analyzed parameters were in agreement with the current legislation (CONAMA 357/05); thereby, guaranteeing the standard of potability of the Corda River water. Principal Component Analysis demonstrated that some parameters such as $\mathrm{pH}$, conductivity, salinity, and nitrite concentration were seasonally sensitive. The most sensitive parameters $(\mathrm{pH}$, conductivity, salinity, and nitrite concentration) can be used as indicators based in the statistical analysis. This study highlights the need for actions that can improve the quality of the Corda river water as per the legal regulations of basic sanitation and socioeconomic development for the preservation of aquatic life.

As for microbiological analysis all samples were positive for E. coli bacteria above the recommended limit, i.e., they were out of potability standard in this analysis. Thus, it can be observed that this work can contribute positively to the adoption of public policies by the municipality with the association of state measures, in order to minimize the problems encountered, as the lack of basic sanitation and the deficiencies in the socioeconomic development of the city. population undermine the water quality of the region, especially the Corda River, which is the object of study, given that there is a direct relationship between water, the environment and public health. 


\section{ACKNOWLEDGMENT}

Thanks to reviewers, collaborators and development agencies.

This part may be placed after the article is approved, so as not to compromise the blind review.

\section{REFERENCES}

ANDRADE FS, SILVA AM, ARIDE PHR, OLIVEIRA AT. Análise físico-química e da microbiota da água do lago Macurany, Parintins, Amazonas. Biota Amazônia (Biote Amazonie, Biota Amazonia, Amazonian Biota). 2016;6(2):132-134.

APHA - American Public Health Association. Standard Methods for the Examination of Water and Wastewater, 20 ed., Washington, DC: Apha, 2012.

Barra do Corda, Secretaria Municipal de Educação. Plano municipal de educação 2015-2025, 83f, 2015.

BEHBAHANI BA, YAZDI F T, SHAHIDI F, MORTAZAVI S A, MOHEBBI M. Principal component analysis (PCA) for investigation of relationship between population dynamics of microbial pathogenesis, chemical and sensory characteristics in beef slices containing Tarragon essential oil. Microbial Patogenesis. 2017;105:37-50.

BELLUTA I, JESUS AS, VIEIRA PM, CORRÊA NM, RALL VLM, VALENTE JPS. Qualidade da Água, Carga Orgânica e de Nutrientes na Foz do Córrego da Cascata: Contribuição da Sub-Bacia para a Represa de Barra Bonita, Rio Tietê (SP) (Water Quality, Organic Loading and Nutrient Loading in the Mouth of Cascata Brook: The Subbasin). Revista Brasileira de Geografia Física. 2016;9(1):305-318.

BEZERRA RAR, MARQUES BS, ALMEIDA FB, SAMPAIO WMS, GIONGO P, SILVAAM. Estudo de variação de turbidez (NTU) do Rio santa maria da vitória, entre os municípios de Santa Maria do Jetibá e Santa Leopoldina Estado do Espírito Santo. Anais Simpac. 2017;7(1).

Brasil Ministério de Minas e Energia. Secretaria de Geologia, Mineração e Transformação Mineral. Geodiversidade do Estado do Maranhão. Programa Geologia do Brasil Levantamento da Geodiversiade, 2013.

CARVALHO FIM, LEMOS VP, DANTAS FILHO HÁ, DANTAS KGF. Avaliação da qualidade das águas subterrâneas de Belém a partir de parâmetros físico-químicos e níveis de elementos traço usando análise multivariada. Revista Virtual de Química.

2015;7(6):2221-2241. 
CODEVASF - Companhia de Desenvolvimento dos Vales do São Francisco e do Parnaíba (2014). Disponível em: http://www.codevasf.gov.br/. Acessado em: 25/09/2017.

COIMBRA CD, CARVALHO G, PHILIPPINI H, SILVA, MFM, NEIVA E. Determinação da concentração de metais traço em sedimentos do estuário do rio MaracaípePE/BRASIL. Brazilian Journal of Aquatic Science and Technology. 2016;19(2):58-75.

DA CONCEIÇÃO FT, BONOTTO DM. Relações hidroquímicas aplicadas na avaliação da qualidade da água e diagnóstico ambiental na bacia do Rio Corumbataí(SP). Geochimica brasiliensis. 2017;16(1):1.

DA SILVA MA, VARGAS RR. Análise de fósforo e DQO em amostras de águas naturais no município de Guarulhos. Revista Educação-UNG-Ser. 2017;11(3):81.

FERNANDES FMSS. Potencial Químico, Fugacidade e Atividade. Revista de Ciência Elementar. 2017;5(4):1-7.

FERREIRA FS, QUEIROZT M, SILVA TV, ANDRADE ACO. À margem do rio e da sociedade: a qualidade da água em uma comunidade quilombola no estado de Mato Grosso. Saúde e Sociedade. 2017;26:822-828.

FREITAS MA. Hidrogeoquímica e isotopia de águas com alta salinidade do Sistema Aquífero Serra Geral na região do Alto Rio Uruguai, Brasil [thesis]. Porto Alegre: Instituto de Geociências, Universidade Federal do Rio Grande do Sul. 2016. 195p. GOIS FA, SOUZA GA, OLIVEIRA MJ, LIMA RS, KOSLOWSKI, LAD. Análise da qualidade da água quanto ao despejo industrial têxtil no Rio dos Índios. Meio Ambiente e Sustentabilidade. 2017;9(5).

HAJIGHOLIZADEH M, MELESSE AM. Assortment and spatiotemporal analysis of surface water quality using cluster and discriminant analyses. Catena; 2017;151:247-258.

HONGYU K. Comparação do GGEbiplot ponderado e AMMI-ponderado com outros modelos de interação genótipo $\times$ ambiente [thesis]. Piracicaba: Escola Superior de Agricultura "Luiz de Queiroz", Universidade de São Paulo; 2015. 155p.

LORDELO LMK, PORSANI JM, BORJA PC. Qualidade físico-química da água para abastecimento humano em municípios do sertão da Bahia: um estudo considerando diversas fontes de suprimento. Revista Águas Subterrâneas; 2018;32(1):97-105. KOLM HE; SIQUEIRAA, MACHADO EC. Influência da pluviosidade na qualidade da água de dois sangradouros do litoral do Paraná, Brasil. Braz. J. Aquat. Sci. Technol.; 2016;20(2):1-11.

MUNIN RM, SUTTI BO, CHIOZZINI VG, BRAGA ES. Relação do fosfato com a formação e degradação da matéria orgânica no sistema hídrico que cruza o município de Mogi das Cruzes (São Paulo, Brasil). Anais do Encontro Nacional de Pós Graduação. 2017;1(1):469-473. 
RIBEIRO MA, CAMARGO E, FRANCA DT, CALASANS JT, BRANCO MSLC, TRIGO AJ. Gestão da Água e Paisagem Cultural. Revista da Universidade Federal de Minas Gerais. 2016;20(2).

SASSOMA ITL, SOUZA IF, AGUIAR NETO AO, CARVALHO CM. Avaliação temporal e espacial de características físico-químicas em águas superficiais do rio Catumbela, Angola. Revista Brasileira de Agricultura Irrigada-RBAI. 2015;9(3):113-126.

VASCONCELOS PES, VIVEIROS TB, ARRAZ AA. Caracterização da Situação Socioeconômica e Ambiental do Município de Barra do Corda após o Implemento da Construção Civil Durante os Anos 2002 à 2010. In: VII CONNEPI-Congresso Norte Nordeste de Pesquisa e Inovação. 2012. 